\title{
Debt Settlement through the Client of the Existence of Limited Partnership Business Entity as a Non- Legal Business Agency in Indonesia
}

\author{
Siti Mahmudah", Etty Susilowati, Yunanto, Siti Malikhatun Badriyah, Amiek Soemarmi, \\ Kornelius Benuf
}

Faculty of Law, Diponegoro University, Semarang, Indonesia

Received: 17/11/2020 Accepted: 04/01/2021 Published: 20/06/2021

\begin{abstract}
A limited partnership or CV is a non-legal entity that is widely used in running a company which can be declared bankrupt. This paper aims to investigate further regarding the consequences of the end of bankruptcy on the existence of CV as a non-legal entity company where there is no separation of assets between $\mathrm{CV}$ and its partners. The research method used is juridical normative, using secondary data consisting of primary legal materials and secondary legal materials, analyzed descriptively analytically. The results of the study reveal that in CV bankruptcy, CV, complementary and limited partners, as for the bankruptcy board, are CV's assets, allies 'original assets and allies' original assets if bound in marriage without a marriage agreement, and joint assets. CV can operate again if the bankruptcy ends in peace or insolvency followed by a grant of rehabilitation. It is based on the current procedure that bankruptcy against the debtor can end because of peace or insolvency which further entitles the debtor to rehabilitation through a process that does not regulate how long the process is and the requirements for a bankruptcy declaration can result in a solvent company being declared bankrupt resulting in general confis cation of the debtor's and debtor's assets no longer operational, it is very detrimental to the debtor. On the other hand, the existence of general confiscation of the debtor's assets which becomes a guarantee for the repayment of the creditors' receivables requires certainty about who can be requested to be declared bankrupt.
\end{abstract}

Keywords: CV, bankruptcy, debt settlement, business entity, existence

\section{Introduction}

In everyday life, the term Cooperation is known which merges into civil action [1]. Actually, the term cooperation has lived and developed in Indonesian society for a long time. This is evidenced by the existence of a culture of "mutual cooperation" which is inherent in the characteristics of the Indonesian nation. The practice of mutual cooperation has existed for a long time in various regions in Indonesia [2]. Between Gotong Royong and Cooperation have the same spirit, which is working together on a job for a common goal. The purpose of cooperation can be grouped into two objectives, namely; economic goals and noneconomic or social goals. The objective of economic cooperation is to make a profit. This advantage is realized by running a company, which is one of the elements that must be present in running the company, while non-economic cooperation is not aimed at seeking profit but rather for social and community goals and helping people in need. as an example of fundraising cooperation to help social development in various fields such as street children education, creative industries, to people's businesses, such as Kitabisa.com [3].

Regarding running the company, we are familiar with various forms of company in society. Based on the owner, the form of the company is divided into private-owned companies and privateowned companies. Private-owned enterprises include business entities in the form of legal entities and non-legal entities. NonLegal Entities include Civil Partnerships as regulated in Article 1618 to Article 1623 of the Civil Code and alliances with Firms and Limited Partnerships as regulated in Article 16 to Article 35 of the KUHD. Based on the data from Ministry of Industry, Republic of Indonesia, the limited partnership (CV) is a non-legal entity that is widely used by the public, as can be seen in Table 1 .

Table 1: Directory of Industrial Companies in Central Java

\begin{tabular}{lll}
\hline No. & Company Form & Number of Companies \\
\hline 1. & Limited Companies & 986 \\
2. & Limited Partnership & 361 \\
3. & Trading business & 346 \\
4. $\quad$ Trading Company & 15 \\
5. $\quad$ Other forms & 2502 \\
\hline \multicolumn{2}{l}{ Total Company Amount } & $\mathbf{4 2 1 0}$ \\
\hline
\end{tabular}

In carrying out business activities there is a possibility that $\mathrm{CV}$ has debts to several creditors whose settlement can be done through a bankruptcy institution, because $\mathrm{CV}$ is one of the debtors that can be requested to be declared bankrupt (Article 1 point 11

Corresponding author: Siti Mahmudah, Faculty of Law, Diponegoro University, Semarang, Indonesia. E-mail: s.article2020@mail.ru 
of Law No.37 of 2004 concerning Bankruptcy and PKPU).

Given that bankruptcy results in general confiscation of the debtor's assets which are subsequently used to pay debtor debts, it is very important to determine who can be petitioned for bankruptcy, especially for companies that are not legal entities where there is no separation of assets between the company and the company. their allies and the absence of requirements regarding the amount of debt to the debtor who is requested to be declared bankrupt, which results in the debtor who is declared bankrupt not necessarily unable to pay the debt but the company cannot be operational and bankruptcy can end in peace and insolvency and the debtor's right to apply for rehabilitation, it is interesting to investigate further due to the end of bankruptcy on CV's existence as a non-legal entity.

\section{Method}

This study uses a normative juridical research method with a statutory approach [4]. The legal data used in this study is secondary data consisting of primary legal materials, namely the law on capture fisheries business and the Law on CV in Indonesia, as well as secondary legal material in the form of literature related to $\mathrm{CV}$ bankruptcy. The collection of data and legal materials through literature study, collated data and legal materials, are then analyzed descriptively and analytically to answer research problems [5].

The material requirements include the existence of separate assets from the personal assets of the parties in a legal entity, the existence of a common interest, the existence of several people who are the administrators of the legal entity, while the formal requirements are recognition from the state of such an entity as a legal entity, through laws and regulations. CV as a business entity has not met the material requirements in the form of "separate assets between CV and its partners, as regulated in Articles 16, 19, 21 of the KUHD and formal requirements, but in practice as can be seen in the following table CV can be a party. in the process of settlement of cases in court, including settlement of debts through bankruptcy submitted to the Commercial Court, as can be seen from the following table 2 :

Table 2: Number of CV Bankruptcy Applications in Semarang, Surabaya and Jakarta District Courts 2016-2019

\begin{tabular}{|c|c|c|c|c|}
\hline No. Year & PN Semarang & $\begin{array}{l}\text { PN } \\
\text { Surabaya }\end{array}$ & PN Jakarta & Amount per year \\
\hline 1. 2016 & 0 & 5 & 3 & 8 \\
\hline 2. 2017 & 2 & 4 & 6 & 12 \\
\hline 2018 & 2 & 10 & 4 & 16 \\
\hline 2019 & 1 & 3 & 3 & 7 \\
\hline \multicolumn{4}{|c|}{ Total number } & 43 Cases \\
\hline
\end{tabular}

Source: Information System for Case Tracing of Semarang District Court, Surabaya District Court and Jakarta District Court

$\mathrm{CV}$ is a non-legal entity, because it has not fulfilled the elements of a legal entity in the form of separation of the company's assets from the assets of its partners. In this regard, CV's creditors are creditors of CV and CV's allies. Thus, the debtor if $\mathrm{CV}$ has debt is $\mathrm{CV}$, and its allies.

\section{Result}

Bankruptcy is a further implementation of the creditor parity principle and the pari pasu prorate parted principle, this is in line with the provisions in Articles 1131 and 1132 of the Civil Code. Furthermore, Article 1 point 1 of the Bankruptcy and PKPU Law provides a definition of Bankruptcy as general confiscation of all assets of the Bankrupt Debtor whose management and settlement is carried out by the Curator under the supervision of the Supervisory Judge as regulated in this Law [6]. Based on the definition of bankruptcy, the bankruptcy results in the assets of the bankrupt debtor being under general confiscation which will then be managed and controlled by the Curator. A statement of bankruptcy does not only affect the assets of the debtor but can also affect the debtor, the engagement between the debtor and the debtor's partner (husband / wife). As a result of the bankruptcy statement against the debtor, the debtor is bankrupt by law, losing the right to manage and control his assets which are included in the assets (budel bankruptcy) since the bankruptcy decision was pronounced.

As a result of the bankruptcy declaration made by the debtor, all debtor engagements issued (which arise) after the pronouncement of the bankruptcy declaration can no longer be paid (fulfilled) from the bankruptcy estate, unless the agreement benefits the bankruptcy estate, as stipulated in Article 25 UUKPKPU. The legal consequences of Article 25 UUK-PKPU, if after the decision on the declaration of bankruptcy the debtor still commits legal actions relating to his assets that have been included in the bankruptcy estate, then the legal action is not binding unless the agreements he made bring profit to him. the bankruptcy estate [7].

The bankruptcy statement also results in the debtor pair being declared bankrupt as regulated in Article 23 UUK-PKPU. If in a marriage there is a union of assets, the property of the husband / wife declared bankrupt, the assets of origin of the spouse and the assets of the joint. Declaration of bankruptcy to debtors is one of the efforts to settle debt through an application for a bankruptcy statement to the Commercial Court, as an implementation of the provisions of Article 1131 of the Civil Code. Requirements for requesting a bankruptcy statement against debtors include the number of creditors and debts. Debtors who have at least two creditors and one of the debts is due and can be requested to be declared bankrupt (Article 2 paragraph 1 UUKPKPU).

$\mathrm{CV}$ is a debtor who can be requested to be declared bankrupt, as stipulated in article 1 point 11 of UUK-PKPU, if it meets the requirements in the form of having at least two creditors and one of the debts is due and can be collected. A debtor is a person who has a debt due to an agreement or law, the payment of which can be collected in court, while a creditor is a person who has a debt due to an agreement or law that can be collected in court. Creditors under UUK-PKPU are differentiated into concurrent, preferred and separatist creditors. Under certain conditions CV can be a concurrent, preferred and separatist creditor if $\mathrm{CV}$ has receivables and is a debtor if it has debt.

Debt is an obligation that is stated or can be stated in an amount of money either in Indonesian currency or foreign currency, either directly or that will arise at a later date or contingent, arising from an agreement or law and which must be fulfilled by the Debtor and if not fulfilled gives the right to the creditor to get the fulfillment from the assets of the Debtor. CV is a non-legal entity, which is established by at least one limited partner and at least one complementary partner, to run the business continuously [8]. Legal Entity (rechtpersoon) which means person (persoon) created by law. Rechtspersoon can be referred to as a legal entity which is a persona ficta or a person 
created by law as a persona, a business entity is said to be a legal entity if it meets formal and material requirements $[9,10]$.

Settlement of CV's debt through a debtor's bankruptcy statement which results in general confiscation of the debtor's assets requires certainty about who can be applied for bankruptcy and whose assets can be general confiscated. UUK-PKPU, does not clearly regulate who can be requested to be declared bankrupt, but UUKPKPU implicitly regulates who can be filed for bankruptcy in $\mathrm{CV}$ bankruptcy as regulated in the provisions of Article 5, but if we base it on the provisions of Article 16, 19 and 21 KUHD, which can be requested to be declared bankrupt are $\mathrm{CV}$, and its allies. Thus, based on the provisions of Articles 16, 19 and 21 of the Criminal Code and Article 5 of the UUK-PKPU due to the critical statement against the debtor in CV bankruptcy, including $\mathrm{CV}$, complementary allies and limited partners, and their respective partners if the allies are bound in marriage with asset union, as regulated in Article 23 UUK-PKPU. Due to bankruptcy declaration of bankruptcy ending with peace on the existence of $\mathrm{CV}$ as a non-legal entity business entity, the bankruptcy statement against the debtor by the Commercial Court aims to provide creditors with access to the debtor's assets to get debt repayment [11]. Debt settlement through a bankruptcy statement against the debtor goes through a process consisting of several stages starting with a decision on the bankruptcy statement and culminating in the end of bankruptcy. The UUKPKPU does not regulate how long the debt settlement process through bankruptcy will end, but regulates several causes that can end bankruptcy, including through peace.

The bankrupt debtor has the right to offer peace to all his creditors (Article 144 UUK-PKPU), but from the point of view of its usefulness a peace proposal in bankruptcy is only relevant for the interests of concurrent creditors whose claims are not guaranteed by the debtor's property rights. Peaceful payment of debt, if it is accepted by the majority of concurrent creditors and approved by the commercial court and executed by the debtor, will benefit the bankrupt debtor as well as the concurrent creditors [12]. The peace plan that has been accepted and then ratified by a commercial court judge results in the bankruptcy property (boedel bankruptcy) not being insolvent and the debtor's debt payments to all of his creditors are made based on a peace agreement that is a win-win solution [13]. Bankruptcy that ends in a settlement in the form of debt payment can be pursued by determining the methods of payment and terms. Another alternative is that the debtor can surrender all of his assets and concurrent creditors will take the fulfilment of their respective receivables by means of settlement that they mutually agree on as stated in the peace deed [14].

The debtor's bankruptcy will end if the confirmation of the peace has obtained permanent legal force (Article 166 paragraph 1 ). With the end of this bankruptcy, the debtor can re-manage his (company) business, and his assets as if there had never been a previous bankruptcy, however, the debtor must always meet the terms and conditions specified in the agreement [7]. Bankruptcy peace is basically an agreement between debtors and creditors, especially concurrent creditors, which contains ways to settle debts. Based on the pacta sunt servanda principle, agreements made legally, including peace in bankruptcy have a binding force as the law for the parties making them (Article 1138 paragraph 1 of the Civil Code). Thus, if the contents of the agreement have been fully implemented by the debtor and creditor based on the pacta sunt servanda principle, the debtor will be freed from the obligations for his old debts even though the creditor does not receive full payment, if it turns out that the debtor does not fulfill his achievement of carrying out the contents of the peace, this situation becomes one of the reasons for creditors to submit a request for cancellation of the agreement to the commercial court and the debtor has the right to file a rebuttal.

A commercial court cannot automatically decide to cancel a peace that has been agreed and ratified. The Commercial Court is obliged to remind the debtor in writing or give a summons to the debtor to fulfill the contents of the peace agreement within 30 (thirty) days and the debtor has the right to file an objection to the request for cancellation. The procedure for examining the request for cancellation of peace is carried out mutatis mutandis with the procedure for applying for bankruptcy. The request for cancellation of peace must be able to prove that the debtor does not fulfill the side of peace, because the basis of the cancellation of the peace is default or broken promise. The end of bankruptcy because the peace also applies to $\mathrm{CV}$ as a debtor who was declared bankrupt. Considering that Law No.37 of 2004 concerning Bankruptcy and PKPU, hereinafter referred to as UUK-PKPU, does not clearly regulate who can be filed for bankruptcy in CV, then based on Article 16 and Article 19, as well as Article 21 of the Criminal Code, the debtor is in bankruptcy. $\mathrm{CV}$ is $\mathrm{CV}$, Complementary ally and allied Commander. If an ally of CV is bound in a marriage with a union of assets, the partner of that partner becomes a debtor who can be declared bankrupt. Thus, the boedel bankruptcy or assets in CV bankruptcy are the assets of $\mathrm{CV}$, complementary allies, and limited partnership allies, along with the original assets of their partners if the allies are bound in marriage with a union of assets and joint assets. This property is used to pay CV's debt to its creditors through peace in bankruptcy and the end of CV's bankruptcy because the legalization of the peace which has permanent legal force causes $\mathrm{CV}$ to operate again.

\section{Discussion}

Due to bankruptcy declaration of bankruptcy ending with insolvency on the existence of $\mathrm{CV}$ as a non-legal entity business entity, not every debtor's debt can be settled through a request for a debtor's bankruptcy statement through the Commercial Court, because only the debtor meets the requirements as stipulated in Article 2 paragraph 1 UUK-PKPU. Based on this requirement, a debtor who is declared bankrupt does not have to be insolvent or bankrupt, likewise a statement of bankruptcy against the debtor does not always result in the debtor being insolvent. The insolvency of the debtor occurs because the debtor does not offer peace, or there is an offer of peace that is approved by the concurrent creditors but the commercial court does not ratify the peace. The assets of the debtor which are declared bankrupt are managed and controlled by the curator. With this authority, if the bankruptcy property is insolvent, then the curator can make sales of the bankruptcy estate, the proceeds of which are used to pay debtors' debts to their creditors. Creditors receiving payment from the sale of bankruptcy assets are creditors whose claims are recognized as registered in the closing List of Distributions, while creditors whose receivables are not recognized or rejected are not considered in the bankruptcy of a debtor. For the unrecognized class of creditors, the legal remedy that can be taken is to file a lawsuit against the debtor after the bankruptcy ends [15].

Debtor debt payments that have been insolvent can be classified into 2 (two) types, namely full payment or in full payment. Bankruptcy that ends in full payment indicates that all 
debtor debts that are recognized have been paid in full by the curator or the Balai Harta Peninggalan from the proceeds from the sale of bankruptcy assets, thus the debtor no longer has the obligation to pay all of his creditors which makes it easier for the debtor to obtain a statement from his creditors. which explains that they have received a satisfactory payment (notification of satisfaction payment), to obtain this statement the debtor does not need to approach or negotiate, because the debtor is free of his old debts. The statement letter from the creditor which states that it has been satisfactorily paid is an attachment that must be included in the application for rehabilitation as regulated in Article 216 UUK-PKPU, meanwhile what is meant by rehabilitation is the restoration of the good name of the Debtor who was originally declared bankrupt, through a Court decision containing the statement that Debtors have fulfilled their obligations (explanation of Article 215UUK-PKPU), whereas what is meant by satisfactory payment is creditors who are admitted to no longer serve claims against debtors, even though they have not received payment of all their invoices (Explanation of Article 216 UUKPKPU).

Bankruptcy that ends in full payment is the end of the real bankruptcy, which restores the dignity of the debtor before the law and in the midst of society. Full payment of debts also indicates that the debtor is in fact only temporarily insolvent or unable to pay his obligations to his creditors due to a lack of cash, which gives the debtor the opportunity to be restored through a request for rehabilitation. Thus, according to UUK-PKPU, debtors who are declared bankrupt which ends in insolvency in the form of full debt payments can operate and regain control of their assets because the debtor does not have the obligation to pay debts to his creditors, which is indicated by the creditors that have stated that they will not collect their assets. the remaining debt is not yet paid, in other words the debtor's debt has been paid off, and the agreement that resulted in the debt has ended, as a result the debtor can manage the company and its assets again even though UUK-PKPU does not explicitly regulate [16, 17]. According to Bagus by juxtaposing the conception of the loss of legal competence experienced by "bankrupt debtors" based on the UUK-PKPU, with the conception of rehabilitation regulated in a series of Articles 215 into Article 221 UUK-PKPU, then "rehabilitation" in bankruptcy, is not only limited to "administrative procedural" only good reputation recovery. Furthermore, this process is an effort that can be taken by the Debtor or his heirs to restore their legal position, so that they are authorized to resume business activities and manage their assets.

The debtor actually still has the obligation to pay debts to his creditors if the bankruptcy ends not with full payment, because the proceeds from the sale of the bankruptcy assets are no longer sufficient, and no debtor's property is found that can be disclosed to pay the remaining debt. This situation becomes one of the obstacles for the debtor to obtain a statement that he has received payment satisfactorily from his creditors, which is a condition for applying for rehabilitation [18]. In other words, debtors who are no longer able to pay their debts will find it difficult to obtain rehabilitation. The end of bankruptcy due to the insolvency of the debtor as mentioned above also applies to $\mathrm{CV}$ which is a debtor in bankruptcy. In $\mathrm{CV}$ bankruptcy that can be bankrupt is $\mathrm{CV}$, complementary allies and limited allies and allies if the ally is bound in marriage with a union of assets. Thus, in CV boedel bankruptcy or CV bankruptcy assets include the assets of CV, complementary allies, and limited partners along with the assets of each partner's partner if the allies are bound in marriage without a marriage agreement or with a union of assets. This boedel bankruptcy was used to pay CV's debt so that CV received rehabilitation. With $\mathrm{CV}$ receiving rehabilitation because it received a statement from creditors which stated that it had been paid satisfactorily, the end of bankruptcy due to insolvency did not make $\mathrm{CV}$ dissolve.

\section{Conclusion}

The application for a bankruptcy statement against $\mathrm{CV}$, includes $\mathrm{CV}$, and its allies, namely complementary allies and limited partners as stipulated in Articles 16, 19 and 21 of the Commercial Law Code, along with their partners if they are bound by marriage by means of a marriage agreement. Boedel bankruptcy in CV bankruptcy which guarantees repayment of creditors' accounts, consists of CV's assets, complementary partners, limited partners and all partner's assets if bound in marriage with a marriage agreement and joint assets. Bankruptcy can end because of peace or insolvency. Bankruptcy settlement is basically an agreement that contains concurrent debtor and creditor agreements on how to settle debts. Bankruptcy that ends because of peace occurs when the ratification of the peace has obtained permanent legal force (Article 166 paragraph 1) which results in $\mathrm{CV}$ being operational again. Bankruptcy that ends because of insolvency can occur because of full payment or in full payment. If the bankruptcy that ends with the insolvency is followed by a rehabilitation grant, then $\mathrm{CV}$ can operate again.

\section{Ethical issue}

Authors are aware of, and comply with, best practice in publication ethics specifically with regard to authorship (avoidance of guest authorship), dual submission, manipulation of figures, competing interests and compliance with policies on research ethics. Authors adhere to publication requirements that submitted work is original and has not been published elsewhere in any language.

\section{Competing interests}

The authors declare that there is no conflict of interest that would prejudice the impartiality of this scientific work.

\section{Authors' contribution}

All authors of this study have a complete contribution for data collection, data analyses and manuscript writing.

\section{References}

1. Asikin, Z. (2013). Perjanjian Kerjasama Antara Pemerintah dan Swasta dalam Penyediaan Infrastruktur Publik. Mimbar HukumFakultas Hukum Universitas Gadjah Mada, 25(1), 55-67.

2. Irfan, M. (2016). Crowdfunding sebagai Pemaknaan Energi Gotong Royong Terbarukan. Share: Social Work Journal, 6(1).

3. Muhammad, A. (2006). Hukum Perusahaan Indonesia, PT. Citra Aditya Bakti, Bandung.

4. Adi, R. (2004). Metodologi penelitian sosial dan hukum. Granit.

5. Soemitro, R. H. (1982). Metode Penelitian Hukum. Jakarta: Ghalia Indonesia.

6. Mahmudah, S. (2012). Tinjauan Yuridis Terhadap Tanggung Jawab Direksi Dalam Kepailitan Perseroan Terbatas Menurut Undang Undang No 40 Tahun 2007. Masalah-Masalah Hukum, 41(3), 472477 
7. Sjahdeini, S. R. (2010). Hukum Kepailitan Memahami UndangUndang No. 37 Tahun 2004 Tentang Kepailitan. Jakarta: Pustaka Utama Grafiti.

8. Adhim, N., Mahmudah, S., \& Benuf, K. (2020). Telaah Yuridis Pemberian Hak Guna Bangunan Kepada Persekutuan Komanditer (CV).

9. Kansil, C. S. T. (1989). Pengantar Ilmu Hukum dan Tata Hukum Indonesia, Cet. Ke-7. Jakarta: Balai Pustaka.

10. Prananingrum, D. H. (2014). Telaah Terhadap Esensi Subjek Hukum: Manusia Dan Badan Hukum. Refleksi Hukum: Jurnal Ilmu Hukum, 8(1), 73-92.

11. Fauzi, M. (2010). Menimbang Konstruksi Hukum Kepailitan Bank; Perspektif Nilai-Nilai Dasar Dan Tujuan Hukum. Risalah Hukum, 1 8.

12. Sofia, A. N. (2020). Kedudukan Hak Suara Kreditor Preferen dalam Persetujuan Rencana Perdamaian Penundaan Kewajiban Pembayaran Utang (PKPU). Jurist-Diction, 3(4), 1415-1430.

13. Rahmadewi, M. R. F. (2007). Penyelesaian utang debitor terhadap kreditor melalui kepailitan (Doctoral dissertation, program Pascasarjana Universitas Diponegoro).

14. Ferdinan, A. (2009). Kekuatan Eksekutorial Sertifikat Jaminan Fidusia Terhadap Objek Jaminan Dalam Kepailitan (Master's thesis).

15. Ginting, E. R. (2018). Hukum Kepailitan Teori Kepailitan. Sinar Grafika, Jakarta.

16. Assalmani, M., \& Priyono, D. (2018). Konsep Pengaturan CrossBorder Insolvency Badan Usaha Di Association Of Southeast Asian Nations (Asean) Dalam Rangka Mewujudkan Asean Economic Integration (Doctoral dissertation, Fakultas Hukum).

17. Shubhan, M. H. (2019). Charging Director of Company with Personal Bankruptcy for Company Mismanagement. Jurnal Hukum dan Peradilan, 8(3), 353-370.

18. Dewanto, R. F. (2008). Kedudukan Kreditur Selaku Penerima Jaminan Fidusia Dalam Hal Debitur Pailit (Doctoral dissertation, Program Pasca Sarjana Universitas Diponegoro). 